\title{
Review: Transforming research methods in the social sciences: Case studies from South Africa
}

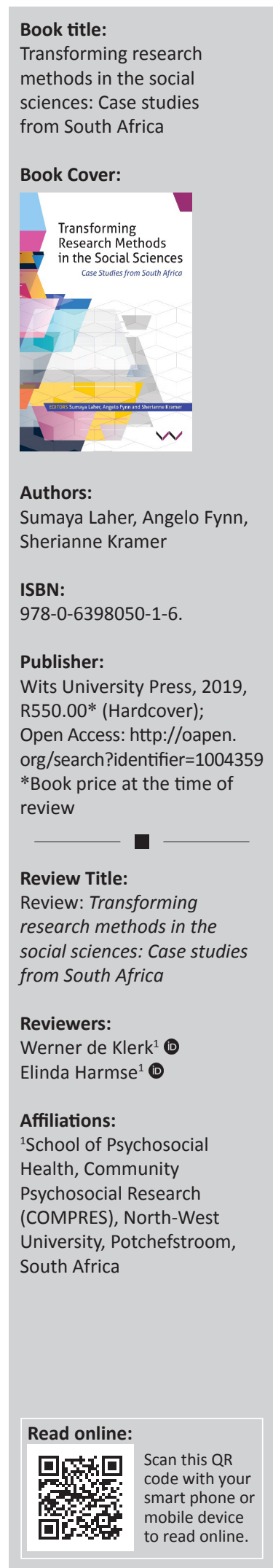

Literature has indicated that research methods play an important role in the quality of research as well as educating young researchers; however, the application thereof is unclear, which can be harmful to the field of psychology (Scholtz, De Klerk, \& De Beer, 2020). The recently published research methodology book by Laher, Fynn and Kramer (2019) was, according to the authors, written in response:

Two fundamental issues facing social sciences in South Africa, namely the active production of knowledge relevant to the South African context and access beyond the sphere of university scholars with subsidised access to scholarly publications. As such, this book is both intentionally open access and context specific. (Kramer, Fynn, \& Laher, 2019, p. 1)

In the light of this statement, as well as the article written by Scholtz et al. (2020), we as reviewers had to ask ourselves, did Laher et al. (2019) achieve what they set out to do?

Laher et al. (2019) mention that the field of social science is ever growing and expanding. Therefore, it can become quite challenging in keeping up with the newest research methods and development thereof. As mentioned by the authors, there have been a number of attempts to create an all-encompassing research book in order to assist scholars, academia and anyone that has an interest in research. Consequently, the authors refrained from using the traditional research methods and rather approached a diverse perspective by using different South African case studies as examples. Taking the above into consideration, this research book consists of three main sections: quantitative (eight chapters), qualitative (nine chapters) and transparadigmatic (six chapters). Transforming research methods in the social sciences is a research methodology book book written by numerous experts that focuses on research in the South African context. It provides techniques, procedures and research methods that can be applied to context-bound issues, and which are relevant to the following fields: psychology, sociology, ethnography and anthropology. Besides the unique combination of theoretical and application issues, each chapter provides the reader with ethical considerations and issues that one may encounter using that particular method within the South African context.

In the words of Fynn, Kramer and Laher (2019, p. xi), 'this book is simply the introductory chapter to, we hope, a larger body of work that will systematically transform how social science research is conducted within the global South'. Taking this statement into consideration, the reviewers recommend that future edited versions of Transforming research methods in the social sciences should also consider including more traditional research methods as case studies within the South African context, as there are many examples of these. Further reading suggestions include research articles published by Scholtz et al. (2020), Coetzee and Van Zyl (2014) and O'Neil and Koekemoer (2016), which provide a broad overview of the use of research methods internationally and nationally within the psychology research context. Other research books such as Doing social research (Wagner, Kawulich, \& Garner, 2012), Research at grass roots (De Vos, Strydom, Fouche, \& Delport, 2011), Doing research in the real world (Gray, 2014), First steps in research (Maree, 2016), The practice of social research (Babbie \& Mouton, 2001), and Research in practice (Terre Blanche, Durrheim, \& Painter, 2006) are also recommended as good reads for students, academia and researchers in practice.

In conclusion, the reviewers are of the opinion that Transforming research methods in the social sciences is very germane in the current South African research context. Any students, academics, scholars and future researchers will benefit from reading this work, as it is broad and has a variety of relevant information with regard to theoretical and applied knowledge. The reviewers acknowledge that the book does not seek to have the ultimate knowledge or answers, however, it can be regarded

Corresponding author: Werner de Klerk, 12998699@nwu.ac.za

Howto cite this book review: De Klerk, W., \& Harmse, E. (2020). Review: Transforming research methods in the social sciences: Case studies from South Africa. African Journal of Psychological Assessment, 2(0), a27. https://doi.org/10.4102/ajopa.v2i0.27

Copyright: @ 2020. The Authors. Licensee: AOSIS. This work is licensed under the Creative Commons Attribution License. 
as an important methodological guide, seeing that it will set the tone and bar for future research and findings to come in the social sciences.

\section{References}

Babbie, E., \& Mouton, J. (2001). The practice of social research (South African edn.) Cape Town: Oxford University Press Southern Africa.

Coetzee, M., \& Van Zyl., L.E. (2014). A review of a decade's scholarly publications (20042013 ) in the South African Journal of Industrial Psychology. South African Journal of Industrial Psychology, 4O(1), 1-16. https://doi.org/10.4102/sajip.v40i1.1227

De Vos, A.S., Strydom, H., Fouché, C., \& Delport, C.S.L. (2011). Research at grass roots (4th edn.). Pretoria: Van Schaik Publishers.

Fynn, A., Kramer, S., \& Laher, S. (2019). Preface. In S. Laher, A. Fynn, \& S. Kramer (Eds.) Transforming research methods in the social sciences: Case studies from South Africa (pp. xi-xii). Johannesburg: Wits University Press. https://doi.org/10. 18772/22019032750.4

Gray, D.E. (2014). Doing research in the real world (3rd edn.). London: Sage.
Kramer, S., Fynn, A., \& Laher, S. (2019). Research as practice: Contextualising applied research in the South African context. In S. Laher, A. Fynn, \& S. Kramer (Eds.) Transforming research methods in the social sciences: Case studies from South Transforming research methods in the social sciences: Case studies from South
Africa (pp. 1-18). Johannesburg: Wits University Press. https://doi. orr $/ 10.18772 / 22019032750.6$

Laher, S., Fynn, A., \& Kramer, S. (2019). Transforming research methods in the socia sciences: Case studies from South Africa. Johannesburg: Wits University Press. https://doi.org/10.18772/22019032750

Maree, K. (2016). First steps in research (2nd edn.). Pretoria: Van Schaik Publishers.

O'Neil, S., \& Koekemoer, E. (2016). Two decades of qualitative research in psychology, industrial and organisational psychology and human resource management within South Africa: A critical review. South African Journal of Industria Psychology, 42(1), 1-16. https://doi.org/10.4102/sajip.v42i1.1350

Scholtz, S.E., De Klerk, W., \& De Beer, L.T. (2020). The use of research methods in psychological research: A systematised review. Frontiers in Research Metrics and Analytics, 5(1), 1-17. https://doi.org/10.3389/frma.2020.00001

Terre Blanche, M., Durrheim, K., \& Painter, D. (2006). Research in practice: Applied methods for the social sciences (2nd rev. edn.). Cape Town: University of Cape Town Press.

Wagner, C., Kawulich, B., \& Garner, M. (2012). Doing social research: A global context. Berkshire: McGraw-Hill Higher Education. 